Tersedia Secara Online di

\title{
Penelitian Beton dengan Penambahan Abu Sekam Padi dan Limbah Keramik sebagai Substitusi Semen
}

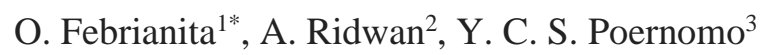 \\ ${ }^{1 * 2,3}$ Fakultas Teknik, Universitas Kadiri. \\ Email : 'olyndiafebrianita02@gmail.com
}

A R T I C L E IN FO

\begin{tabular}{l} 
Article history : \\
Artikel masuk $: 07-10-2020$ \\
Artikel revisi $: 09-10-2020$ \\
Artikel diterima $: 12-10-2020$ \\
\hline \\
Keywords : \\
Lightweight Concrete, Rice Husk \\
Ash, Ceramic Waste, Cement \\
Substitution.
\end{tabular}

Style IEEE dalam mensitasi artikel ini: [15] M. S. Nadesan and P. Dinakar, "Mix design and properties of fly ash waste lightweight aggregates in structural lightweight concrete," Case Stud. Constr. Mater., vol. 7, no. May, pp. 336-347, 2017

\begin{abstract}
A B S T R A C T
Concrete is a technology that continues to develop in the construction sector. Continues to increase in terms of cost. The need for materials to form concrete requires innovation in the use of concrete mixtures. One of them is using the innovation of rice husk ash and ceramic waste. These ingredients is held in the cement content, namely rice husk ash containing silica and ceramic waste containing alumina. The method used refers to the Indonesian National Standard with a cylindrical specimen measuring $15 \times 30 \mathrm{~cm}$ tested at 28 days, and the planned quality is $f_{c}$ ' $14.5 \mathrm{Mpa}$. The research objective was to determine the compressive strength and slump value by adding a mixture of rice husk ash 3\%, 6\%, 9\%, $12 \%$, and ceramic waste $3 \%$ by weight of cement. The results showed that the slump value decreased with the lowest value of $13.5 \mathrm{~cm}$. the results of the compressive strength of concrete with the addition of rice husk ash and ceramic waste have not achieved the planned quality. The average compressive strength that has the highest value is the addition of $9 \%$ rice husk ash with 9\% ceramic waste, namely 6.53 Mpa.
\end{abstract}

\section{A B S T R A K}

Beton merupakan salah satu teknologi yang terus berkembang di bidang konstruksi. Terus meningkat dari segi biaya, Kebutuhan bahan untuk membentuk beton membutuhkan inovasi dalam penggunaan campuran beton. Salah satunya dengan inovasi pemanfaatan abu sekam padi dan limbah keramik. Bahan tersebut tertahan di dalam kandungan semen yaitu abu sekam padi yang mengandung silika dan limbah keramik yang mengandung alumina. Metode yang digunakan mengacu pada Standar Nasional Indonesia dengan spesimen silinder berukuran $15 \times 30 \mathrm{~cm}$ yang diuji pada 28 hari, dan kualitas yang direncanakan adalah fc '14 .5 Mpa. Tujuan penelitian untuk mengetahui kuat tekan dan nilai slump dengan menambahkan campuran abu sekam padi $3 \%, 6 \%, 9 \%$, $12 \%$, dan limbah keramik $3 \%$ dari berat semen. Hasil 
Penelitian menunjukkan nilai slump mengalami penurunan dengan nilai terendah $13,5 \mathrm{~cm}$. Hasil kuat tekan beton dengan penambahan abu sekam padi dan limbah keramik belum mencapai kualitas yang direncanakan. Kuat tekan rata-rata yang memiliki nilai tertinggi adalah penambahan abu sekam 9\% dengan limbah keramik 9\% yaitu 6,53 Mpa.

\section{Pendahuluan}

Seiring berkembangnya era yang semakin maju, manusia dituntut untuk lebih kreatif dan inovatif dalam mengembangkan teknologi yang ada. Terutama pada teknolgi beton yang memiliki fungsi sangat luas dalam bidang konsruksi [1]. Beton merupakan material yang terdiri dari campuran semen Portland, air, agregat kasar (kerikil), agregat halus (pasir) dan bahan tambahan jika dibutuhkan [2]. Memberikan bahan tambah yang bersifat organik dan non organik dapat meningkatkan kualitas mutu beton. Bahan tambah bias sebagai pengganti sebagian semen atau mengurangi agregat [3].

Pada penelitian ini akan menggunakan bahan tambahan abu sekam padi dan limbah keramik pada campuran beton sebagai pengganti sebagian semen. Abu sekam padi adalah limbah hasil pertanian yang dibakar sampai menjadi abu. Kandungan silica yang terdapat dalam abu sekam padi sebanyak 86,90-97,30\% [4]. Namun dalam teknologi abu sekam padi belum banyak dimanfaatkan dengan baik. Dengan melihat kandungan silica yang cukup tinggi dapat digunakan sebagai substitusi semen untuk campuran beton tergantung kehalusan abu sekam padi yang akan meningkatkan kemampuan kerja beton [5].

Limbah keramik adalah sisa produksi keramik yang hasilnya tidak sesuai dengan ukuran. Serpihan limbah keramik ini akan dihancurkan sampai menjadi bubuk dan dapat dimanfaatkan lagi untuk pembuatan keramik. Hasil dari penghancuran limbah keramik berupa butiran halus dengan ukuran 0,075 mm-0,15 mm [6]. Butiran halus dari keramik dapat menjadi bahan tambah pada campuran beton dari segi bahan dasarnya keramik terbuat dari tanah lempung yang bersifat plastis. Bubuk keramik ini kemungkinan dapat mengurangi dampak produksi semen dan juga berkontribusi pada beton berkelanjutan tanpa mengurangi kinerja beton [7].

Bahan yang dapat dibentuk sesuai dengan keinginan, material yang mudah didapat dan mudah dalam penggerjaannya menjadi keuntungan beton sebagai bahan bangunan. Oleh karena itu beton menjadikan pilihan utama untuk konstruksi suatu bangunan [8]. Dengan penggunaan abu sekam padi dan limbah keramik sebagai bahan dalam penelitian ini diharapkan dapat memberikan inovasi-inovasi lebih lanjut untuk mendapatkan bahan campuran beton dan dapat menghasilkan beton yang baik. 


\section{Studi Literatur}

Berdasarkan penelitian terdahulu terdapat beberapa penelitian yang menjadi landasan dilakukannya penelitian beton dengan campuran abu sekam padi dan limbah keramik yaitu : penelitian yang telah dilakukan oleh Sri Raharja, Sholihin As'ad, Sunarmasto (2013) dengan judul Pengaruh Penggunaan Abu Sekam Padi Sebagai Bahan Pengganti Sebagian Semen Terhadap Kuat Tekan dan Modulus Elastisitas Beton Kinerja Tinggi. Dengan kesimpulan nilai kuat tekan mengalami peningkatan dan nilai modulus elastisitas mengalami penurunan [9]. Adapun penelitian lain yang dilakukan oleh Revisdah, Ririn Utari (2018) yang berjudul Pemanfaatan Limbah Keramik Terhadap Kuat Tekan, menghasilkan nilai slump yang kecil dan kenaikan pada nilai kuat tekan beton [3].

\subsection{Beton}

Beton adalah campuran yang terdiri dari agregat kasar, agregat halus, semen Portland, air dan bahan tambahan (admixture). Beton yang menggunakan agregat alam yang dipecah atau tidak dipecah tanpa member bahan tambahan dapat menghasilkan beton normal dengan berat isi $2200-2500 \mathrm{~kg} / \mathrm{m}^{3}$ [10]. Bahan baku dalam produksi beton mengalami jumlah yang besar, sehingga pengurangan dalam penggunaan bahan baku akan menghasilkan banyak manfaat bagi lingkungan terutama dengan memanfaatkan produk sampingan atau limbah [11].

\subsubsection{Beton Ringan}

Beton ringan dapat dibuat dengan menginjeksikan udara atau menghilangkan ukuran agregat yang lebih halus dengan mengganti agregat berongga. Agregat kasar yang digunakan berukuran maksimum $10 \mathrm{~mm}$ dan $20 \mathrm{~mm}$ [12]. Beton ringan adalah beton yang memiliki berat jenis (density) lebih ringan dibandingkan beton normal dan dapat dibuat menggunakan agregat ringan dan memiliki berat volume $400-1900 \mathrm{~kg} / \mathrm{m}^{3}$ [13].

\subsection{Material Penyusun Beton}

\subsubsection{Semen Portland}

Semen adalah suatu bahan pengikat yang dihasilkan dengan cara menghaluskan klinker yang berupa bubuk halus. Memiliki sifat adhesive dan kohesif sehingga dapat mengeras jika bereaksi dengan air [14].

\subsubsection{Agregat}

Kandungan agregat yang terdapat dalam beton cukup tinggi sekitar $60-70 \%$ dari berat campuran beton. Agregat merupakan bahan yang terpenting dikarenakan komposisi 
yang dominan dan menyangkut sifat beton yang matang dalam campuran beton [15].

a. Agregat halus

Agregat halus (pasir) sangat menentukan dalam pengerjaan (workability), kekuatan (strength), dan keawetan (durability) dari beton yang dihasilkan. Agregat halus tidak boleh mengandung lumpur lebih dari 5\% terhadap jumlah agregat kering [16].

b. Agregat kasar

Agregat kasar merupakan butiran yang mempunyai diameter 5mm-40mm. Agregat kasar tidak boleh mengandung lumpur lebih dari 1\% karena sifat agregar kasar dapat memepengaruhi daya tahan terhadap beton [17].

\subsubsection{Air}

Dalam campuran beton dibutuhkan air sekitar 25-30\% dari berat semen yang berfungsi sebagai pelumas agregat dan semen untuk memberikan reaksi pengerasan pada beton. Kelebihan air pada beton membuat adukan mudah dikerjakan, akan tetapi beton menjadi porus dan nilai kuat tekan menurun [18].

\subsection{Bahan Pengganti Parsial Semen}

\subsubsection{Abu Sekam Padi}

Sekam padi yang dibakar pada temperature $600-900^{\circ} \mathrm{C}$ menghasilkan kadar silica sekitar 87-97\%. Abu sekam padi yang dibakar dengan suhu sekitar $400-500^{\circ} \mathrm{C}$ akan menghasilkan silica amorphous, sedangkan dibakar pada suhu lebih dari $1000^{\circ} \mathrm{C}$ menghasilkan silica kristalin [19]. Abu sekam padi memiliki struktur partikel berpori dan tidak beraturan dengan ukuran diameter rata-rata $87 \mu \mathrm{m}$ yang diukur menggunakan Mastersizer 2000 [20].

\subsubsection{Limbah Keramik}

Limbah keramik merupakan limbah hasil dari sisa konstruksi bangunan atau keramik yang tidak lolos dalam pengolahan pabrik yang nantinya dihaluskan sampai menjadi bubuk atau serbuk. Serbuk keramik ini berupa butiran halus yang berukuran sekitar 0,075 mm-0,15 mm [6]. Penambahan keramik yang mengandung kapur bersifat plastis yang berfungsi sebagai pozzolan yang dapat berpotensi menggantikan semen dan menghasilkan daya rekat pada agregat dalam campuran beton. 


\subsection{Kuat Tekan Beton}

Kuat tekan beton adalah besarnya beban per satuan luas, benda uji beton hancur bila dibebani gaya tekan yang dihasilkan oleh mesin tekan. Faktor utama yang menentukan kekuatan beton adalah perbandingan air terhadap semen [21]. Adapun hal-hal yang dapat mempengaruhi kuat tekan beton yaitu faktor air semen, umur beton, jenis semen, efisiensi perawatan (curing) dan sifat agregat. Perhitungan kuat tekan beton dapat dinyatakan dengan persamaan pada SNI 1974-2011 tentang Cara Uji Kuat Tekan Beton dengan Benda Uji Silinder [22].

Kuat tekan beton $=\frac{\mathrm{P}}{\mathrm{A}}$

Dimana :

Kuat tekan beton $=$ Dinyatakan dalam $(\mathrm{MPa}$ atau N/mm²)

$\mathrm{P} \quad$ = Gaya tekan aksial, dinyatakan dalam Newton $(\mathrm{N})$

A $\quad=$ Luas penampang benda uji, dinyatakan dalam $\left(\mathrm{mm}^{2}\right)$

Sumber : SNI 1974-2011

\section{Metode Penelitian}

Metode penelitian ini adalah metode eksperimental yaitu penelitian yang dilakukan dengan mengadakan suatu percobaan secara langsung. Penelitian dilakukan di Laboratorium Teknik Sipil Universitas Kadiri dengan mengacu pada Standar Nasional Indonesia. Pada penelitian ini menggunakan benda uji berupa silinder berukuran 15 x $30 \mathrm{~cm}$ yang berjumlah 15 sampel dengan persentase campuran abu sekam padi 3\%, 6\%, 9\%, 12\% dan limbah keramik 3\% dan akan diuji pada umur 28 hari.

\subsection{Alur Penelitian}

Tahapan penelitian ini dimulai dari persiapan bahan penyusun beton, kemudian dilakukan pengujian agregat halus dan kasar untuk mengetahui standart bahan yang akan digunakan. langkah selanjutnya yaitu pembuatan campuran beton sesuai perhitungan jobmix yang sudah ditentukan dan pengujian slump, setelah pengujian slump dilakukan percetakan beton didalam begisting silinder yang didiamkan selama 2 hari, kemudian dilakukan proses perawatan (curing) selama 28 hari. Pada umur beton 28 hari dilakukan pengujian kuat tekan beton, adapun tahap penelitian akan disajikan pada Gambar 1 berikut. 


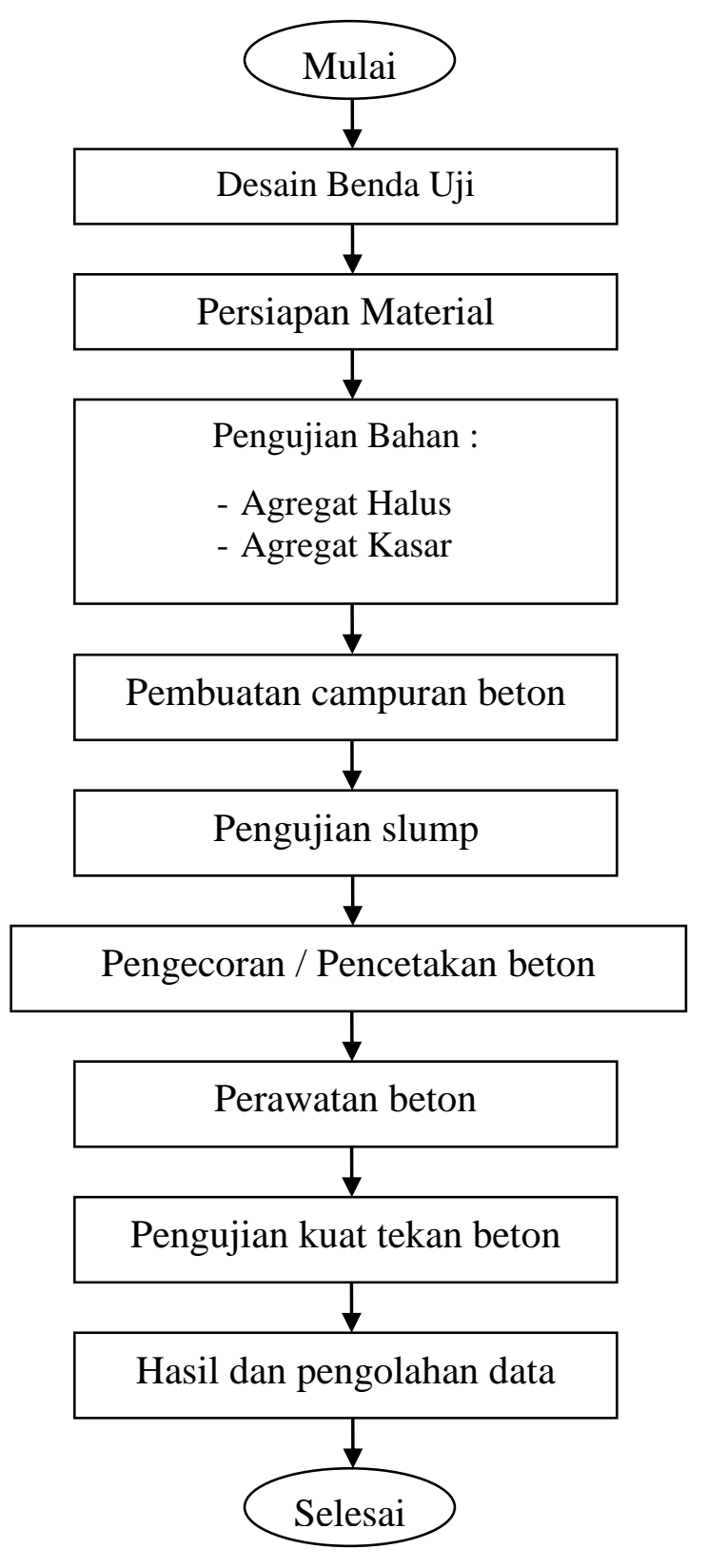

Sumber : Analisa Alur Penelitian.

Gambar 1. Bagan Alur Penelitian.

\section{Hasil dan Diskusi}

Hasil dan pembahasan dari penelitian ini meliputi hasil pengujian agregat, pengujian slump, dan hasil kuat tekan yang telah dilakukan di Laboratorium Teknik Sipil Universitas Kadiri.

\subsection{Hasil Pengujian Agregat}

Hasil Pengujian agregat ini meliputi agregat kasar (batu pecah) dan halus (pasir), pengujian ini perlu dilakukan terlebih dahulu untuk mengetahui karakteristik dari agregat yang akan digunakan. 
Tabel 1. Rekapitulasi Hasil Pengujian Agregat Halus.

\begin{tabular}{|c|c|c|c|c|}
\hline No & $\begin{array}{c}\text { Karakteristik } \\
\text { Agregat }\end{array}$ & $\begin{array}{c}\text { Interval } \\
\text { Spesifikasi }\end{array}$ & Hasil Uji & Keterangan \\
\hline 1 & Kadar Air & $2 \%-5 \%$ & $3,95 \%$ & Memenuhi \\
\hline 2 & Kadar Lumpur & Maks 5\% & $2,44 \%$ & Memenuhi \\
\hline \multirow[t]{3}{*}{3} & Berat Volume & & & \\
\hline & a. Lepas & $1.6-1.9 \mathrm{~kg} / \mathrm{liter}$ & 1,61 & Memenuhi \\
\hline & b. Padat & $1.6-1.9 \mathrm{~kg} / \mathrm{liter}$ & 1,64 & Memenuhi \\
\hline 4 & Absorpsi & Maks $2 \%$ & $1,83 \%$ & Memenuhi \\
\hline \multirow[t]{4}{*}{5} & Berat Jenis & & & \\
\hline & a. Bj Curah & $1.6-3.3$ gram & 2,94 & Memenuhi \\
\hline & b. Bj Kering Permukaan & $1.6-3.4$ gram & 2,99 & Memenuhi \\
\hline & c. Bj Semu & $1.6-3.8$ gram & 3,11 & Memenuhi \\
\hline 6 & Modulus Halus Butir & $1.5-3.8$ gram & 3,47 & Memenuhi \\
\hline
\end{tabular}

Sumber : Analisa Hasil Perhitungan Agregat Halus

Hasil pengujian agregat halus didapatkan persentase kadar air 3,95\% dari hasil tersebut memenuhi persyaratan persentase kadar air 2\%-5\%.

Tabel 2. Rekapitulasi Hasil Pengujian Agregat Kasar.

\begin{tabular}{llccc}
\hline No & \multicolumn{1}{c}{$\begin{array}{c}\text { Karakteristik } \\
\text { Agregat }\end{array}$} & $\begin{array}{c}\text { Interval } \\
\text { Spesifikasi }\end{array}$ & Hasil Uji & Keterangan \\
\hline 1 & Kadar Air & $0.5 \%-2 \%$ & $0,60 \%$ & Memenuhi \\
2 & Kadar Lumpur & $0.2 \%-1 \%$ & $0,64 \%$ & Memenuhi \\
3 & Berat Volume & & & \\
& a. Lepas & $1.4-1.9 \mathrm{~kg} / \mathrm{liter}$ & 1,43 & Memenuhi \\
& b. Padat & $1.4-1.9 \mathrm{~kg} / \mathrm{liter}$ & 1,43 & Memenuhi \\
4 & Absorpsi & Maks 3\% & $1,21 \%$ & Memenuhi \\
5 & Berat Jenis & & & \\
& a. Bj Curah & $1.6-3.3$ gram & 3,11 & Memenuhi \\
& b. Bj Kering Permukaan & $1.6-3.3$ gram & 3,14 & Memenuhi \\
& c. Bj Semu & $1.6-3.3$ gram & 3,23 & Memenuhi \\
6 & Keausan & Maks $40 \%$ & 29,4 & Memenuhi \\
\hline
\end{tabular}

Sumber : Analisa Hasil Perhitungan Agregat Kasar

Pada pengujian kadar lumpur agregat kasar didapat persentase 0,64\% dari persyaratan $0,2 \%$ - 1\%, sehingga hasil kadar lumpur memenuhi. 


\subsection{Hasil Perhitungan Rencana Campuran (Job Mix)}

Metode komposisi campuran yang digunakan mengacu pada SNI 7394:2008 tentang Adukan Beton Setiap $1 \mathrm{~m}^{3}$. Dalam penelitian ini mutu yang direncanakan adalah $f c^{\prime} 14,5$ atau setara dengan K-175 dengan jumlah sampel 3 pada setiap variasi. Komposisi campuran akan disajikan dalam Tabel 3. sebagai berikut.

Tabel 3. Komposisi Kebutuhan Bahan Campuran Beton.

\begin{tabular}{cccccccc}
\hline $\begin{array}{c}\text { Kode } \\
\text { Benda } \\
\text { Uji }\end{array}$ & Variasi & Semen & Pasir & Kerikil & $\begin{array}{c}\text { Air } \\
\begin{array}{c}\text { Abu } \\
\text { Sekam } \\
\text { Padi }\end{array}\end{array}$ & $\begin{array}{c}\text { Limbah } \\
\text { Keramik }\end{array}$ \\
\cline { 3 - 8 } & & $(\mathrm{Kg})$ & $(\mathrm{Kg})$ & $(\mathrm{Kg})$ & $($ Liter $)$ & $(\mathrm{Kg})$ & $(\mathrm{Kg})$ \\
\hline BT-N & - & 326,0 & 760,0 & 1029,0 & 215,0 & - & - \\
BT-V1 & ASP 3\% dan LK 3\% & 306,4 & 760,0 & 1029,0 & 215,0 & 9,78 & 9,78 \\
BT-V2 & ASP 6\% dan LK 3\% & 277,1 & 760,0 & 1029,0 & 215,0 & 19,56 & 9,78 \\
BT-V3 & ASP 9\% dan LK 3\% & 238,0 & 760,0 & 1029,0 & 215,0 & 29,34 & 9,78 \\
BT-V4 & ASP 12\% dan LK 3\% & 189,1 & 760,0 & 1029,0 & 215,0 & 39,12 & 9,78 \\
\hline
\end{tabular}

Sumber : Data Rencana Bahan Campuran Beton

BT-V1 merupakan Beton Variasi 1 campuran Abu sekam padi (ASP) 3\% dan Limbah keramik (LK) 3\% dari berat semen untuk mengurangi penggunaan semen. Pada BTV1 ini memerlukan kebutuhan bahan semen 5,85 kg, pasir 14,50 kg, kerikil/batu pecah 19,63 $\mathrm{kg}$, air 4,10 liter, abu sekam padi 0,19 kg dan limbah keramik 0,19 kg.

\subsection{Hasil Pengujian Slump}

Pengujian slump dilakukan untuk mengetahui kekentalan campuran beton yang memberikan kemudahan pada proses pengerjaan (workability) beton.

Tabel 4. Hasil Pengukuran Slump.

\begin{tabular}{ccc}
\hline Kode & Variasi & Nilai Slump \\
\cline { 3 - 3 } Benda Uji & - & $(\mathrm{cm})$ \\
\hline BT-N & ASP 3\% dan LK 3\% & 16,0 \\
BT-V1 & ASP 6\% dan LK 3\% & 15,5 \\
BT-V2 & ASP 9\% dan LK 3\% & 15,0 \\
BT-V3 & ASP 12\% dan LK 3\% & 14,5 \\
BT-V4 & .
\end{tabular}


BT-V1 merupakan Beton Variasi 1 campuran Abu Sekam Padi (ASP) 3\% dan Limbah Keramik (LK) 3\% dari berat semen sebagai bahan pengganti parsial semen yang memiliki nilai slump $15,5 \mathrm{~cm}$. Hasil pengujian slump menunjukkan bahwa semakin besar penambahan abu sekam padi dan limbah keramik pada campuran beton, maka akan menurunkan sifat workability beton.

\subsection{Hasil Pengujian Kuat Tekan Beton}

Pengujian kuat tekan beton dilakukan menggunakan mesin kuat tekan hidrolis dengan kekuatan tekan mencapai 500 ton. Metode yang digunakan berdasarkan SNI 1974:2011 tentang Cara Uji Kuat Tekan Beton dengan Benda Uji Silinder yang diuji pada umur 28 hari.

Tabel 4. Hasil Kuat Tekan Beton Normal.

\begin{tabular}{ccccc}
\hline \multirow{2}{*}{$\begin{array}{c}\text { Nomor } \\
\text { Benda Uji }\end{array}$} & $\begin{array}{c}\text { Berat Basah } \\
(\mathrm{Kg})\end{array}$ & $\begin{array}{c}\text { Berat Kering } \\
(\mathrm{Kg})\end{array}$ & $\begin{array}{c}\text { Mutu Beton Fc' } \\
(\mathrm{Mpa})\end{array}$ & $\begin{array}{c}\text { Mutu Beton K } \\
\left(\mathrm{Kg} / \mathrm{cm}^{2}\right)\end{array}$ \\
\hline BT-N.1 & 12,430 & 12,390 & 11,32 & 136,43 \\
BT-N.2 & 12,585 & 12,540 & 13,02 & 156,89 \\
BT-N.3 & 12,600 & 12,565 & 14,72 & 177,35 \\
\hline
\end{tabular}

Sumber : Analisa Hasil Perhitungan Kuat Tekan Beton Normal.

Pengujian kuat tekan beton normal pada sampel 3 dengan berat basah 12,600 kg, berat kering $12,565 \mathrm{~kg}$ menghasilkan kuat tekan beton $f_{c}^{\prime}$ 14,72 Mpa atau setara dengan beton K-177.

Tabel 5. Hasil Kuat Tekan Beton Variasi Abu Sekam Padi 3\% dan Limbah Keramik 3\%.

\begin{tabular}{ccccc}
\hline \multirow{2}{*}{$\begin{array}{c}\text { Nomor } \\
\text { Benda Uji }\end{array}$} & $\begin{array}{c}\text { Berat Basah } \\
(\mathrm{Kg})\end{array}$ & $\begin{array}{c}\text { Berat Kering } \\
(\mathrm{Kg})\end{array}$ & $\begin{array}{c}\text { Mutu Beton Fc' } \\
(\mathrm{Mpa})\end{array}$ & $\begin{array}{c}\text { Mutu Beton K } \\
\left(\mathrm{Kg} / \mathrm{cm}^{2}\right)\end{array}$ \\
\hline BT-V1.1 & 12,465 & 12,440 & 7,93 & 95,50 \\
BT-V1.2 & 12,595 & 12,565 & 8,49 & 102,32 \\
BT-V1.3 & 12,720 & 12,695 & 11,89 & 143,25 \\
\hline
\end{tabular}

Sumber : Analisa Hasil Perhitungan Kuat Tekan Beton Variasi Abu Sekam Padi 3\% dan Limbah Keramik 3\%. 
Pada pengujian kuat tekan beton variasi campuran abu sekam padi 3\% dan limbah keramik 3\% dari berat semen menunjukkan bahwa sampel 3 dengan berat basah 12,720 kg, berat kering $12,695 \mathrm{~kg}$ menghasilkan kuat tekan beton $f_{c}$ ' 11,89 Mpa atau setara dengan beton K-143.

Tabel 6. Hasil Kuat Tekan Beton Variasi Abu Sekam Padi 6\% dan Limbah Keramik 3\%.

\begin{tabular}{ccccc}
\hline \multirow{2}{*}{$\begin{array}{c}\text { Nomor } \\
\text { Benda Uji }\end{array}$} & $\begin{array}{c}\text { Berat Basah } \\
(\mathrm{Kg})\end{array}$ & $\begin{array}{c}\text { Berat Kering } \\
(\mathrm{Kg})\end{array}$ & $\begin{array}{c}\text { Mutu Beton Fc' } \\
(\mathrm{Mpa})\end{array}$ & $\begin{array}{c}\text { Mutu Beton K } \\
\left(\mathrm{Kg} / \mathrm{cm}^{2}\right)\end{array}$ \\
\hline BT-V2.1 & 12,385 & 12,360 & 7,36 & 88,68 \\
BT-V2.2 & 12,555 & 12,530 & 11,32 & 136,43 \\
BT-V2.3 & 12,550 & 12,525 & 10,19 & 122,78 \\
\hline
\end{tabular}

Sumber : Analisa Hasil Perhitungan Kuat Tekan Beton Variasi Abu Sekam Padi 6\% dan Limbah Keramik 3\%

Pada pengujian kuat tekan beton variasi dengan campuran abu sekam padi $6 \%$ dan limbah keramik 3\%. Pada sampel 2 dengan berat basah 12,555 kg, berat kering 12,530 kg menghasilkan kuat tekan beton $f c^{\prime}$ 11,32 Mpa atau setara dengan beton K-136.

Tabel 7. Hasil Kuat Tekan Beton Variasi Abu Sekam Padi 9\% dan Limbah Keramik 3\%.

\begin{tabular}{ccccc}
\hline \multirow{2}{*}{$\begin{array}{c}\text { Nomor } \\
\text { Benda Uji }\end{array}$} & $\begin{array}{c}\text { Berat Basah } \\
(\mathrm{Kg})\end{array}$ & $\begin{array}{c}\text { Berat Kering } \\
(\mathrm{Kg})\end{array}$ & $\begin{array}{c}\text { Mutu Beton Fc' } \\
(\mathrm{Mpa})\end{array}$ & $\begin{array}{c}\text { Mutu Beton K } \\
\left(\mathrm{Kg} / \mathrm{cm}^{2}\right)\end{array}$ \\
\hline BT-V3.1 & 12,145 & 12,125 & 9,06 & 109,14 \\
BT-V3.2 & 12,170 & 12,670 & 7,36 & 88,68 \\
BT-V3.3 & 12,165 & 12,145 & 10,19 & 122,78
\end{tabular}

Sumber : Analisa Hasil Perhitungan Kuat Tekan Beton Variasi Abu Sekam Padi 9\% dan Limbah Keramik 3\%

Pengujian kuat tekan beton variasi dengan campuran abu sekam padi $9 \%$ dan limbah keramik 3\% Pada sampel 3 dengan berat basah 12,165 kg, berat kering $12,145 \mathrm{~kg}$ menghasilkan kuat tekan beton $f_{c}$ ' 10,19 Mpa atau setara dengan beton K-123. 
Tabel 8. Hasil Kuat Tekan Beton Variasi Abu Sekam Padi 12\% dan Limbah Keramik 3\%.

\begin{tabular}{ccccc}
\hline \multirow{2}{*}{$\begin{array}{c}\text { Nomor } \\
\text { Benda Uji }\end{array}$} & $\begin{array}{c}\text { Berat Basah } \\
(\mathrm{Kg})\end{array}$ & $\begin{array}{c}\text { Berat Kering } \\
(\mathrm{Kg})\end{array}$ & $\begin{array}{c}\text { Mutu Beton Fc' } \\
(\mathrm{Mpa})\end{array}$ & $\begin{array}{c}\text { Mutu Beton K } \\
\left(\mathrm{Kg} / \mathrm{cm}^{2}\right)\end{array}$ \\
\hline BT-V4.1 & 12,170 & 12,140 & 8,49 & 102,32 \\
BT-V4.2 & 12,100 & 12,075 & 6,23 & 75,03 \\
BT-V4.3 & 12,135 & 12,110 & 6,79 & 81,86 \\
\hline
\end{tabular}

Sumber : Analisa Hasil Perhitungan Kuat Tekan Beton Variasi Abu Sekam Padi 12\% dan Limbah Keramik 3\%.

Pengujian kuat tekan beton variasi campuran abu sekam padi 12\% dan limbah keramik 3\% dari berat semen. Pada sampel 1 dengan berat basah 12,170 kg, berat kering $12,140 \mathrm{~kg}$ menghasilkan kuat tekan beton $f c^{\prime}, 8,49 \mathrm{Mpa}$ atau setara dengan beton $\mathrm{K}-102$.

Adapun hasil keseluruhan dari pengujian kuat tekan beton akan disajikan dalam bentuk grafik yang dapat menggambarkan nilai kuat tekan rata-rata beton pada setiap variasi campuran. pada Gambar 2. Berikut penyajian grafik kuat tekan rata-rata beton.

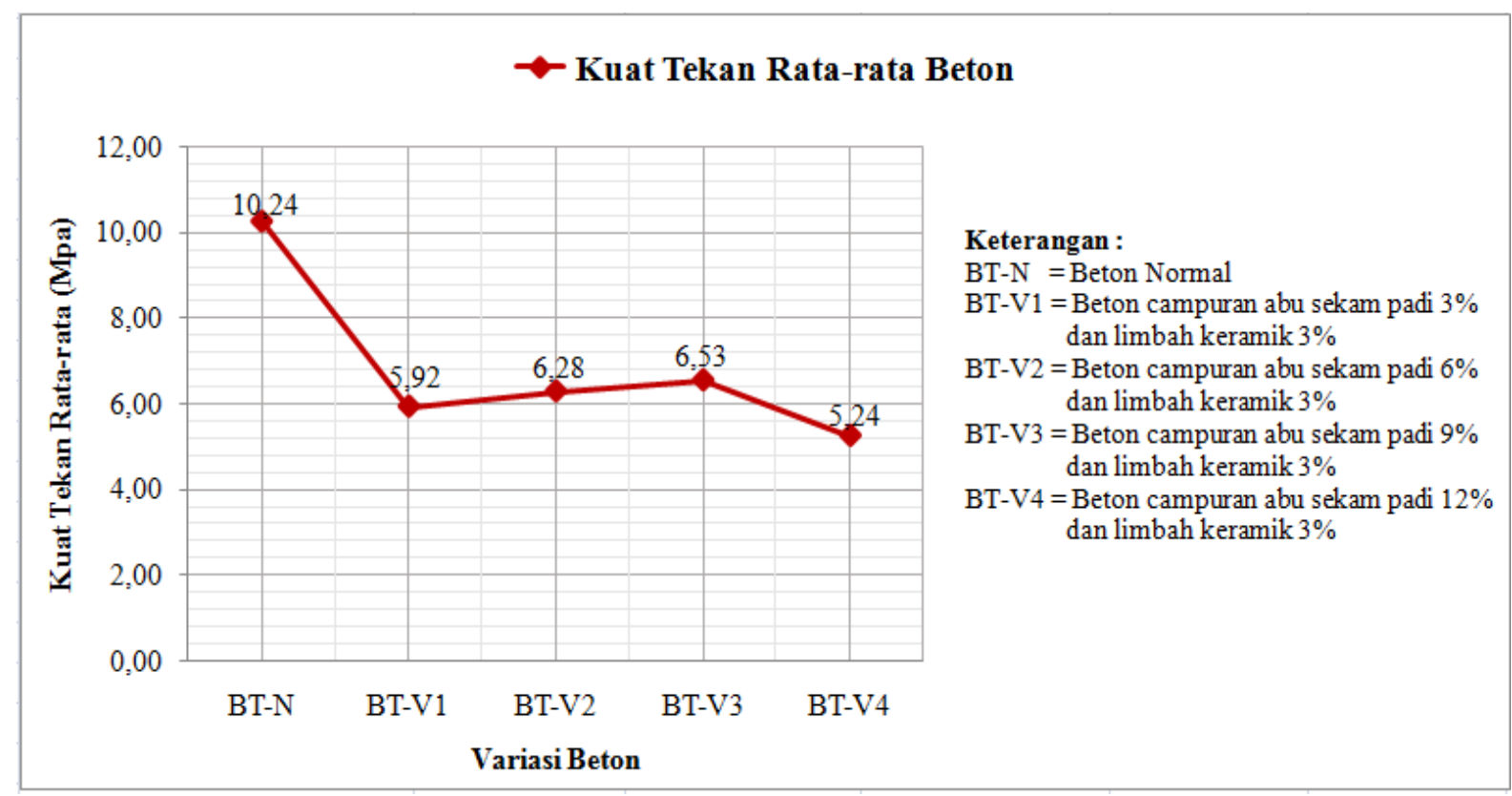

Sumber : Analisa Hasil Perhitungan Test Kuat Tekan Rata-rata Beton.

Gambar 2. Grafik Kuat Tekan Rata-Rata Beton.

Berdasarkan grafik kuat tekan rata-rata yang didapat menunjukkan beton campuran abu sekam padi dan limbah keramik mengalami penurunan dari beton normal. Adapun hasil kuat tekan beton dengan campuran abu sekam padi dan limbah keramik yang optimum terdapat pada beton variasi 2 (BT-V2) dengan campuran abu sekam padi $9 \%$ dan limbah keramik $3 \%$. 


\section{Kesimpulan dan Saran}

\subsection{Kesimpulan}

Berdasarkan penelitian beton dengan penambahan abu sekam padi dan limbah keramik sebagai substitusi semen yang dilakukan di Laboratorium Teknik Sipil Universitas Kadiri , maka dapat diambil kesimpulan sebagai berikut :

1. Hasil pengujian kuat tekan beton dengan penambahan campuran abu sekam padi dan limbah keramik pada umur 28 hari memiliki rata-rata yang berbeda. Nilai kuat tekan beton normal tertinggi mencapai 14,72 MPa dengan rat-rata 10,24 Mpa, sedangkan nilai kuat tekan beton yang paling optimum dengan campuran abu sekam padi dan limbah keramik hanya mencapai 6,53 Mpa pada variasi 3.

2. Nilai slump yang dihasilkan dengan penambahan campuran abu sekam padi $3 \%, 6 \%$, $9 \%, 12 \%$ dan limbah keramik $3 \%$ berturut-turut 15,5 cm, 15,0 cm, 14,5 cm, 13,5 cm.

\subsection{Saran}

Berdasarkan hasil kesimpulan, disarankan untuk dilakukan pengujian benda uji pada variasi abu sekam padi dan limbah keramik, sehingga dapat mengetahui perbandingan dari berbagai bahan yang digunakan. Pada penelitian selanjutnya diharapkan menggunakan alat pemadat beton, agar proses pemadatan lebih baik dibandingkan secara manual karena berpengaruh dalam nilai kuat tekan beton. 


\section{Daftar pustaka}

[1] Y. Cahyo and R. Ajiono, "ANALISA JOBMIX NILAI MUTU BATU BATA DENGAN MENGGUNAKAN LIMBAH ABU SERAT TEBU DAN ABU SERBUK GERGAJI," UkaRsT, vol. 1, no. 1, pp. 55-63, 2017.

[2] R. Hepiyanto and D. Kartikasari, "PENGARUH CAMPURAN AIR LIMBAH (AIR SELOKAN) TERHADAP KUAT TEKAN BETON f'c 14.5 Mpa (K-175)," UkaRsT, vol. 2, no. 2, 2018 .

[3] Revisdah and R. Utari, "PEMANFAATAN LIMBAH KERAMIK TERHADAP KUAT TEKAN BETON,” Pros. Semnastek, 2018.

[4] F. S. Ridwan, "ANALISIS PENGARUH PEMANFAATAN ABU SEKAM SEBAGAI FILLER PADA CAMPURAN ASPAL BETON," Konstruksia, vol. 8, no. 2, pp. 1-8, 2017.

[5] S. H. Kang, S. G. Hong, and J. Moon, "The use of rice husk ash as reactive filler in ultra-high performance concrete," Cem. Concr. Res., vol. 115, no. March, pp. 389-400, 2019, doi: 10.1016/j.cemconres.2018.09.004.

[6] A. S. Huda and Suprapto, "Pengaruh Limbah Keramik Sebagai Pengganti Agregat Halus Terhadap Mutu Beton,” J. Kaji. Pendidik. Tek. Bangunan, vol. 3, no. 1, 2013.

[7] D. M. Kannan, S. H. Aboubakr, A. S. EL-Dieb, and M. M. Reda Taha, "High performance concrete incorporating ceramic waste powder as large partial replacement of Portland cement," Constr. Build. Mater., vol. 144, pp. 35-41, 2017, doi: 10.1016/j.conbuildmat.2017.03.115.

[8] A. Ridwan, S. Winarko, and E. Siswanto, "Jobmix beton mengunakan pasir lumajang dan penambahan additive masterpozzolith ${ }^{\circledR} 402 \mathrm{R}$, , J. CIVILLa, vol. 3, no. 2, pp. 192197, 2018.

[9] S. Raharja, S. As'ad, and Sunarmasto, "Pengaruh Penggunaan Abu Sekam Padi Sebagai Bahan Pengganti Sebagian Semen Terhadap Kuat Tekan Dan Modulus Elastisitas Beton Kinerja Tinggi," e-Jurnal Matriks Tek. Sipil, vol. 1, no. 4, pp. 503$510,2013$.

[10] M. A. Anshori, A. Ridwan, and Y. C. SP, "PENELITIAN UJI KUAT TEKAN BETON DENGAN MEMANFAATKAN AIR LIMBAH TETES TEBU DAN ZAT ADDITIVE CONCRETE," Jurmateks, vol. 2, no. 1, pp. 16-28, 2019.

[11] M. Aslam, P. Shafigh, M. Z. Jumaat, and M. Lachemi, "Benefits of using blended waste coarse lightweight aggregates in structural lightweight aggregate concrete," $J$. 
Clean. Prod., vol. 119, pp. 108-117, 2016, doi: 10.1016/j.jclepro.2016.01.071.

[12] M. M. Al Bakri Abdullah, K. Hussin, M. Bnhussain, K. N. Ismail, Z. Yahya, and R. A. Razak, "Fly ash-based geopolymer lightweight concrete using foaming agent," Int. J. Mol. Sci., vol. 13, no. 6, pp. 7186-7198, 2012, doi: 10.3390/ijms13067186.

[13] S. Puro, "KAJIAN KUAT TEKAN DAN KUAT TARIK BETON RINGAN MEMANFAATKAN SEKAM PADI DAN FLY ASH DENGAN KANDUNGAN SEMEN 350 kg/m3," J. Ilm. Media Eng., vol. 4, no. 2, p. 97931, 2014.

[14] E. Siswanto and A. Gunarto, "PENAMBAHAN FLY ASH DAN SERAT SERABUT KELAPA SEBAGAI BAHAN PEMBUATAN BETON," UKaRsT, vol. 3, no. 1, pp. $56-65,2019$.

[15] M. S. Nadesan and P. Dinakar, "Mix design and properties of fly ash waste lightweight aggregates in structural lightweight concrete," Case Stud. Constr. Mater., vol. 7, no. May, pp. 336-347, 2017, doi: 10.1016/j.cscm.2017.09.005.

[16] S. Winarto, "Pemanfaatan Serat Ijuk Sebagai Material Campuran Dalam Beton Untuk Meningkatkan Kemampuan Beton Menahan Beban Tekan Studi Kasus: Pembangunan Homestay Singonegaran Kediri,” UKaRsT, vol. 1, no. 1, pp. 1-10, 2017.

[17] E. Hunggurami, M. E. Bolla, and P. Messakh, "PERBANDINGAN DESAIN CAMPURAN BETON NORMAL MENGGUNAKAN SNI 03-2834-2000 DAN SNI 7656:2012,” Tek. Sipil, vol. VI, no. 2, pp. 165-172, 2017.

[18] A. I. Candra, E. Gardjito, Y. Cahyo, and G. A. Prasetyo, "Pemanfaatan Limbah Puntung Rokok Filter Sebagai Bahan Campuran Beton Ringan Berpori," UKaRsT, vol. 3, no. 1, p. 82, 2019, doi: 10.30737/ukarst.v3i1.365.

[19] Y. Sandya and S. Musalamah, "PENGGUNAAN ABU SEKAM PADI SEBAGAI PENGGANTI SEMEN PADA BETON GEOPOLIMER,” Educ. Build. J. Pendidik. Tek. Bangunan dan Sipil, vol. 5, no. 2, pp. 59-63, 2019.

[20] H. Chao-Lung, B. Le Anh-Tuan, and C. Chun-Tsun, "Effect of rice husk ash on the strength and durability characteristics of concrete," Constr. Build. Mater., vol. 25, no. 9, pp. 3768-3772, 2011, doi: 10.1016/j.conbuildmat.2011.04.009.

[21] M. I. Saifuddin, B. Edison, and K. Fahmi, "Pengaruh Penambahan Campuran Serbuk Kayu Terdahap Kuat Tekan Beton,” J. Mhs. Tek., vol. 1, no. 1, 2013.

[22] S. 1974:2011, "SNI 1974:2011 tentang Cara Uji Kuat Tekan Beton dengan Benda Uji Silinder," Badan Stand. Nas., p. 20, 2011. 